\title{
Management of Regional Social and Economic Conflicts Under the Conditions of The Russian Crisis 2014-2017: Case of The Republic of Tatarstan
}

\author{
${ }^{1}$ Andrey G. Bolshakov, ${ }^{2}$ Dilya R. Garifullina \\ ${ }^{1}$ Professor, Doctor of Political Sciences, Head of Department of Conflictology, Kazan Federal University \\ ${ }^{2}$ Assistant of the Chair of Conflictology, Kazan Federal University \\ *Email:bolshakov_andrei@mail.ru, dilya-g@mail.ru
}

\section{Received: 15th December 2017, Accepted: 20th December 2017, Published: 31st December 2017}

\begin{abstract}
This paper analyzes various regional conflicts in the conditions of the current Russian social and economic crisis. These conflicts are universal, and arise even in dynamically developing territories and in donor regions. As an example, the case of the Republic of Tatarstan is used. The paper deals with the four-link typology of modern, mainly economic conflicts, which prevail today in the Republic of Tatarstan and other regions of Russia. These include: social and labor conflicts; conflicts of property division (in the most intensive form - illegal seizures); conflicts of development companies and equity holders due to unleased housing; conflicts of financial insolvency of a number of banks. Two types of conflicts have no institutional framework for regulation, and another two encourage protests and social tension. The process of conflict management is considered through the degree of effectiveness of mechanisms and practices of the activities of regional authorities in various situations. The most destructive and socially dangerous in the last two years are the conflicts in the banking sector of the Russian regions. In Tatarstan, the impossibility of paying depositors to several banks at once led to the banking crisis and its strict regulation through the revocation of licenses by the National Bank of Russia.
\end{abstract}

Keywords: Socio-Economic Crisis, Regional Economic Conflicts, Type of Economic Conflict, Social and Labor Conflicts, Owner Conflicts, Shared Construction Conflicts, Conflicts of Financial Bank Insolvency.

\section{Introduction}

The Republic of Tatarstan is one of the most stable subjects of the federation of modern Russia. Throughout the post-Soviet period, Tatarstan was a donor region, characterized by progressive development, implementation of innovative infrastructure projects, and receipt of significant amounts from the federal center to finance largescale cultural and sporting events.

The Republic of Tatarstan belongs to those territories of Russia where the imperious (state) resource clearly dominates the entrepreneurial and public resources, but it to a large extent serves as a source of innovation, development and preservation of stability.

A strip of relative instability was characteristic of the republic in 2010-2013. However, open conflicts were relatively small at that time. They can be attributed to the ethno-confessional sphere, the implementation of the migration policy of the state at the regional level. Most of these conflicts can be defined as criminal-domestic clashes. It should be noted that Tatarstan in this period was characterized by mainly intra-religious and intra-ethnic conflicts. Conflicts such as the burning of the Kryashen churches in the regions of the republic were an exception to the rules.

In general, during this period, the situation was managed to be kept under control. The merit in this belongs to the republican authorities, although it was impossible to prevent threats without the help of the federal center (for example, when carrying out special operations against religious extremists).

In 2014-2016, these conflicts took second place, became much less intense or ended, while social and labor conflicts, confrontations related to the problems of co-investors, business conflicts etc. began to come to the fore in the Republic of Tatarstan (as in most other regions). There are virtually no serious political conflicts, ethnic and religious tension in the republic.

\section{Methods}

The theoretical and methodological framework of this paper is the concept of de-escalation of the conflict, developed by the well-known Russian conflict expert A.V. Dmitriev. He believes that the probability of socio-political destabilization exists in any society, and Russia is characterized by constantly changing geopolitical and internal conditions [1]. For scientific research, this circumstance creates additional difficulties and new analytical problems. Especially important is the study of "preservation of stability", which provides for "de-escalation of the most significant conflicts" [2].

According to A.V. Dmitriev, an important scientific task for the conflictologist is to examine the mental foundations of the discursive construction of stability, as well as the regional specifics of conflicts 
[3]. Significant is the problem of how the priorities for influencing conflicts in the aspect of regional policy are built up; a strategy for the further development of the latter is defined. Of particular importance is the analysis of social and political risks of the economic crisis on a regional scale, the degradation of statehood, the spread of violence, and the unification of extremist and radical forces.

In economic instability, the most important problems are the development of regional models for the consolidation of resources and mechanisms for ensuring national and regional security. In connection with the multifaceted nature of Russian society, the regional level of analysis is mostly important [4]. The threats expressed in conflicts, accompanied by terrorism and extremism, create serious tension and call into question the future development of the Russian Federation. Identifying the factors of the consolidation of society, the relationship between federal and regional tensions, external and internal challenges and threats, involves discussing the problem of consolidation primarily on the part of the expert community [5].

\section{Results}

The socio-economic crisis of 2014-2017 exacerbated the problems of regional inequality, led to the impoverishment of various social groups, reduced revenues to budgets of various levels, and led to the lack of funds to finance a number of projects and development programs.

The current level of social inequality in the Russian regions, the unresolved social problems of the majority make the process of de-escalation of conflicts much more difficult, especially the process of consolidation. In the environment, where the interests of the majority of people are aimed at their own survival, "it is difficult to talk about the possibility of its unity, first of all, in views on the fair distribution of property and income, living conditions and employment, which is especially important for groups with low incomes" [6].

It is clear that this state of affairs creates the ground for increasing the number of economic contradictions and conflicts in the regions of Russia. Moreover, they become ubiquitous. However, according to Russian sociologist G.V. Eremichev, "there is an urgent need in society for determining the prerequisites and values for its consolidation" [7]. Hence, it follows that "the discovery of these prerequisites in a heterogeneous society for today and a complex crisis situation, the analysis of various directions of social policy that can influence the success of this process is one of the priorities for further research"[8].

\section{Discussion}

Typologically, we can distinguish four types of conflicts that prevail today in the Republic of
Tatarstan and other regions of Russia. These include: social and labor conflicts; conflicts of property division (in the most intensive form - illegal seizures); conflicts of development companies and equity holders due to unleased housing; conflicts of financial insolvency of a number of banks of the republic.

The first two types of conflicts are carried out in certain and sufficiently rigid institutional frameworks of conflict regulation, connected with the norms of legislation. Social and labor conflicts, as a rule, remain within this framework, and the legal norms demonstrate their relative effectiveness. The regulation of the ownership section or its transfer to another owner is predominantly governed by the norms of the current legislation, but they do not always solve the existing contradictions, therefore at the present stage, various subjects of the market economy can take forceful actions and seize property, hence the phenomenon of illegal takeover exists to this day.

The situation with the conflicts of the third and fourth types in the Republic of Tatarstan is typical for the social and economic crisis and the unstable economy. In the case of shared construction and nonfulfillment of its obligations by the developer these are permanent protests of the victims (not of a large scale nature, but permanent with the use of modern street and information technologies of protest action). Such situations are regulated, first of all, through mechanisms of "manual control", which are carried out by the first persons of the republic and the city of Kazan.

The most explosive situation for public stability is the fourth type of conflict, as a result of the regional banking crisis with the all-Russian consequences and the possible massive street protests of dissatisfied citizens. The existing institutions (for example, bankruptcy) are not effective; legal norms often do not work. The population turns their protests to regional and city authorities that do not have sufficient resources to regulate such protests because of the redistribution of taxes by the federal center in favor of depressed regions.

The authorities of the Republic of Tatarstan, as an exit from the situation, proposed a mechanism for resolution and found the subject of this possible reorganization - the group of companies "TAIF" known in the republic and abroad. However, such regulation of the situation was not a plan of the National Bank of the Russian Federation.

On March 3, 2017, the federal banking authorities decided to revoke licenses from several Tatarstan banks. This meant the actual bankruptcy of these organizations, the dismissal of their personnel and the absence of payments to deceived depositors, who were mainly represented by small and medium-sized businesses (legal entities), NPOs (legal entities), and individuals. To facilitate the situation of people, the 
leadership of Tatarstan was able to make payments to the majority of individuals who had insured deposits, and the rest were rejected such payments. As a result, the situation around the depositors, which calmed down in early 2017, once again became tense and controversial, which led to open and unauthorized meetings of some of them in front of the Cabinet of Ministers. Saving for the authorities was a small scale of protests. Maximum 200-300 people took part in unauthorized actions; only 700 to 2000 protesters came out in favor of A. Navalny in March 2017 (according to various estimates), where only a part of them were dissatisfied with the banking policy conducted in the republic.

The republican authorities were forced to think about changing all plans for their actions. In the republic, there were several high-profile arrests of people who, according to the investigators, were guilty of financial fraud of bankrupt banks; in addition, the leader of the shared development company "FON" A. Livada, who was accused of fraud related to housing construction, which resulted in hundreds of people suffered, who never got their homes, or got it a few years after the contractual term.

On April 3, Prime Minister of the Republic of Tatarstan and Head of the Board of Trustees of Tatfond bank I. Khalikov resigned. The protesters called this their political victory, but the authorities of the republic interpreted this replacement as planned and long awaited.

Apparently, the prospects for large-scale protests in the republic in the near future are minimal. Risks to manage the economy are more likely to be virus attacks on the territory from abroad, which cause great damage to local companies associated with high technology. Probably, the banking crisis will not repeat, because as a result of the latest events of late 2016 - early 2017 the most troubled banks left the market, but compensation for losses to investors will determine the agenda of the Tatarstan economy for a long time.

On April 26, 2017, the general public was informed about the existence of a new plan for resolving the consequences of the banking crisis in the Republic of Tatarstan. This took place at a meeting between Russian President Vladimir Putin and RT President R. Minnikhanov. Later, the main parameters of this plan became known, which caused an ambiguous assessment on the part of authorities, financial experts and the investors themselves [9].

A few days after this event, the State Council of Tatarstan approved the creation of a mechanism to assist the deceived customers of the regional banks through the establishment of a land fund. This decision deprived the depositors of Tatfond bank and other affected credit institutions of the possibility of a relatively quick return of their money. Many of them chose the court path, as required by the Deposit
Insurance Agency. The positive judicial practice, which only began to develop for depositors in the region, was quickly changed, the courts began to totally refuse to satisfy such claims, hoping for a fund, which terms of establishment still remain undetermined.

According to changes in the Land Code of the Republic on granting land to a special fund for assistance to clients of banks that have collapsed, investors are required to transfer part of the profits from projects to the fund, due to which payments will be made to the deceived customers. The deadline for this mechanism to be ready is unknown. A land for rent in the republic without tendering can be claimed by an investor with a project amounting to more than 350 million rubles.

The authorities of the republic planned that due to this fund the deceived depositors of Tatarstan banks who were illegally transferred to service in the affiliated company "TFB-finance" will help. Such clients accounts for about 1.7 thousand people with the amount of claims of about 2 billion rubles [10]. However, the Cabinet of Ministers of Tatarstan actually deprived investors of a real chance to pay.

\section{Summary}

According to the deceived depositors themselves, "first the courts made positive decisions, but in May the situation turned the opposite direction - it happened after President of the Republic of Tatarstan R. Minnikhanov promised that the republic itself will solve the issue with the victims through the creation of a special fund" [11]. Obviously, after the initiative with the fund, no positive decisions can be expected for those who are not direct depositors.

According to experts, "even if the project with the fund is implemented, it will be able to receive a profit not earlier than in three to five years, while in the situation of compensation to investors it should be about reasonable time limits". They believe that reaching profit in three years (in case it will be development) or in five years (if it will be a production start-up) is the ideal scenario. In reality, "the very fact of the availability of land lots for the organization of industrial production and development does not imply a demand for them from investors, if we consider that the money will not go directly to the victim, but first to the budget, then a real solution to the primary problem can be striven for years" [12].

The return of funds through the Deposit Insurance Agency was unequivocally more promising: compensation could be expected to be received within several months. Apparently, the authorities of Tatarstan chose a different scenario to avoid collapse in the banking market of the republic, which is the first priority, and not payments to the deceived depositors. 
Of course, the case of the financial collapse of Tatfond bank and other banks is the case that attracts close attention to the situation in the republic. But other specific examples of all types of socioeconomic conflicts in the Republic of Tatarstan are no less important. This is the case with the New Year protest flash-mob of the frustrated residents of the Salavat Kupere complex in Kazan, which became known throughout the Russian Federation due to its originality.

Much attention should be paid to the case of nonpayment of debts (more than 4 million rubles) for wages in the city of Chistopol at the shipyard and the actions of the city prosecutor's office, which initiated an administrative case against the general director, as the plant ignored the department's demands to eliminate the situation.

Another solution to the social and labor conflict in the Republic of Tatarstan was also resonant, when at the end of December 2016 a criminal case was opened due to the unpaid salary in the amount of almost 8 million rubles to employees of the JSC "Plemennoi zavod krolika" in Kazan. More than 80 of its workers did not receive salary from August to November 2016.

\section{Conclusion}

Thus, the legislative regulation of social and labor conflicts is a relatively autonomous sphere in the modern conflict resolution. The mechanisms of social partnership (in reality, social dialogue) between employers, trade unions and the government are relatively effective in the Republic of Tatarstan. The socio-economic crisis and its consequences (rising prices, the number of unemployed, a decrease in real incomes of the population, etc.), an increase in non-institutionalized economic conflicts and protests cannot yet destroy the overall stability in Tatarstan. Moreover, some branches of the national economy of the republic show development and growth of their economic indicators.

However, the lack of clear rules and regulations for the division of income from taxes between the federal center and the regions can destroy the relative stability of donor regions. Then the consequences of the crisis and acute economic conflicts without institutional regulation and financial support for a number of donor regions will be unpredictable.

\section{Acknowledgements}

The work is performed according to the Russian Government Program of Competitive Growth of Kazan Federal University.

\section{References}

1. Bolshakov A.G. Information and analytical tools of regional modernization in the Republic of Tatarstan: the impact of the crisis and elections on the situation in $2016 / /$ The Left Policy. 2017. No. 27. p. 92-94.

2. Vasilieva I. Authorities of Tatarstan have prepared a secret plan for saving victims of bankruptcy? // Evening Kazan. 2017. April 27.

3. Galkin V. A ghost of poverty for the middle class // Signs of the future: a left view on the prospects for global development. M.: Klyuch-S, 2016. p. 14-22.

4. Dmitriev A.V. De-escalation of conflicts as a way of stabilizing regional societies // Social factors of consolidation of Russian society: sociological dimension / Ed. member corr. RAS M.K. Gorshkov. M., Novyi Khronograf, 2010. Section 8. P. 256.

5. Eremichev G.V. Social inequality as a negative factor in the process of consolidation // Preconditions and opportunities for the consolidation of Russian society. Collected Works of the Siberian Branch of the Russian Academy of Sciences / Chief Ed.: A.V. Duka, I.I. Eliseeva. St.P.: Nestor-Istoriiay, 2010. p. 280.

6. LokshinaIu., Petrova P. The depositors' money are committed to earth // Kommersant. 2017. May 11 .

7. Markov V., Ershov A., Korzhenko V. Problems and prospective approaches to the organization of municipal development in Russia // Vlast. 2016. No.1. p. 15-22.

8. New factors of global and regional development: aggravation of ethno-sociocultural contradictions / Ed. E.Sh. Gontmakher, N.V. Zagladin, I.S. Semenenko. M.: IMEMO RAS, 2013. p. 119.

9. Ochkina A. Russian regions during the global crisis // The Left Policy. 2014. No.22. p. 60-65.

10. Prediction of socio-political processes and conflicts in Western and Russian countries / Editorial: V.I. Pantin, I.S. Semenenko, V.V. Lapkin, K.G. Kholodovskii. M.: IMEMO RAS, 2016. p. 183. 